Ике туган, бергәкилсә, сандугачтайсайрашыр.

Карамакүзенд, кара нәселено.

Кардәшкардәшнекабергәкадәрташламьий.

Нәсел-нәселгә, тилчә-тамырга.

Тату туганнарташтанкоймакорганнар.

Туганнартатульгыьбайлыктанартык.

Туганыңяманбулса да, исән-әманбулсын.

Ата-бабасынискәалмаганкешечгелеккүрмәс.

Ата-анасына игелек күрсәтмәгән,

Ольгайгач үзе дә игелек күрмәс.

Ата-анасын хурлаган үзен хурлаган бульр.

Атанунь башыңда тот,

Айаңуны учьццда тот![7]

(татар мақал-мәтелдері)

Қорытынды.Қазақ-татар мақал-мәтелдерінде «үлкенге көрсетілетін құрмет баланың міндеті» екені айтылады. Инабат үлгісінің бастауы отбасында алған тәрбиеге байланысты болатынын пайымдаған түркі халықтары «Ата көрген оқ жонар, шеше көрген тон пішер» деп түйінді сөз айтқан. Үлкенді сыйлап, олардың алғысына бөленген, батасын алған ұл-қыздарының мерейі үстем болып, өркені өсе беретінін бір-ақ ауыз сөзбен дәлелдей білген[8].

Мақал-мәтелдер - әр халықтың ғасырлар бойы жинаған асыл мұрасы. Ол - халықтың рухани қазынасы. Рухани қазына -ата-бабамыздың тәлім-тәрбиесі, олардың жан дүниесіндегі адамгершілік құндылықтары. Бұл жас ұрпақты адамгершілікке, имандылыққа, елін, жерін сүюге тәрбиелейтін бірден-бір баға жетпес құрал болмақ.

Пайдаланылван ддебиеттер тізімі:

1 Қазақ ддебиетінің тарихы. - Алматы, 1960.

2 Түркі хальқтарының фольклоры. - Көкшетау, 2009. - 4326.

3 Волков Г.Н. Чувашская народная педагогика. - Чебоксары, 1956.

4 Балабекова К. Ш., Отарбекова Ж.К. Қазақ фольклорындавы дәстүрлі ментальдік және ұлттық танылм/ Абай атындавы ҚазҰПУ-дың Хабаршысы, «Филология» сериясы, Nol (67), 2019 ж.

5 Садыққова Р., Танаева Д. Парсы және құзақ тілдерінің мавынасы жавынан ұқсас мақал-мәтелдердің, қолданылу ерекшеліктері/ Абай атындавы ҚазҰПУ-дың, Хабаршысы, «Филология» сериясы, о2 (40), 2012 ж.

6 Қазақ мақал-мәтелдері. Құраст.жсән ауд. Аққозин М. - Алматы, «Алматыкітап» баспасы, 2012. - 2726.

7 Татар хальк ижсаты. Мәкальләр һәм әйтемнәр. - Казан, Татар. кит. нәшрияты, 1987. - 5926.

8 «Түркілік тәрбие» антологиясы. - Алматы, Интеллсервис, 2013. - 10046.

1. Qazaq ädebietınin tarihy. - Almaty, 1960.

References:

2. Türk halyqtarynyñ fölklory. - Kökşetau, 2009. - 432b.

3. Volkov G.N. Chuvaşskaia narodnaia pedagogika. - Cheboksary, 1956. 4

4. Balabekova Q. Ş., Otarbekova J.K. Qazaq fölkloryndağy dästürlı mentäldıkjäne ūlttyq tanym/Abai atyndağy QazŪPU-dyñ Habarşysy, «Filologia» seriasy, Nol (67), 2019j. 5

5. Sadyqova R., Tanaeva D. Parsy jäne qazaq tılderınıñ mağynasy jăgynan ūqsas maqal-mätelderdiñ qoldanylu erekşelıkterl/ Abai atyndağy QazŪPU-dyñ Habarşysy, "Filologia» seriasy, No2 (40), 2012 j. 6

6. Qazaq maqal-mätelderı. Qürast.jäne aud. Aqqozin M. - Almaty, «Almatykutap» baspasy, 2012. - 272 b. 7

7. Tatar halyk iжçaty. Mäkällär häm äitemnär. - Kazan, Tatar. kit. näşriaty, 1987. - 592 b. 8

8. «Türkllı tärbie» antologiasy. - Almaty, İntelservis, 2013. - 1004b.

МРНТИ 17.07.29 https://doi.org/10.51889/2020-4.1728-7804.45

\author{
Асылбекұльь С., ${ }^{1}$ Аширов Ж.С., ${ }^{2}$ Куттыьбаев Ш.Д. ${ }^{3}$ \\ 1,2,3 Абай атындавы Қазақ ұлттық педагогикалық университеті, \\ Алматы, Қазақстан
}

МОДЕРНИЗМ ТАРИХИ-ӘЛЕУМЕТТІК АСПЕКТІДЕ

\title{
Аңдатпа
}

Бұл мақалада әдебиет пен өнердің дамуына әсер еткен модернистік бағыттың теориялық мәселелері мен алғышарттары қарастырылады. Жалпы XIX ғасырдың аяғы мен XX ғасырдың басында өнер мен мәдениеттегі 
секілді әдебиет те жаңаша бағытқа бет бұрды. Өйткені әдеби модернизмнің пайда болуына әсер ететін негізгі фактор - адам дамуының тарихи және әлеуметтік өміріндегі жаһандық өзгерістер екені сөзсіз. Еуропалық мәдениет пен өнердің ерекшеліктері әдебиет пен көркемдік кеңістік контекстінде қарастырылады. Тарихи-әлеуметтік факторлар мен әдебиет пен өнердегі тың жаңалықтарды тудыратын факторлар арасындағы байланыс анықталды. ХІХ ғасыр соңы мен XX ғасырдың алғашқы ширегіндегі әлем шын мәнінде небір дүрбелеңді жаңалықтарға толы болды. Адамзат дамуының осы кезеңдегі сатысына көз салсақ, XX ғасыр басындағы әлемде жан-жақты және түбегейлі өзгерістер жүріп жатты. Бүгінгі биіктіктен адам дамуының осы кезеңіне қарап, XX ғасырда көп қырлы және түбегейлі өзгерістерге ұшырағанын көреміз. Еуропа әдебиетінен бастау алған бұл жаңашылдық өзгерістер қазақ әдебиетін де дамытып, әдеби алтын қорымызды жаңа шығармалармен толықтырды.

Түйін сөздер: модернизм, әдебиет, өнер, қазақ прозасы

$$
\begin{gathered}
\text { Asylbekuly S., }{ }^{\text {Ashirov Zh., }}{ }^{2} \text { Kuttybaev Sh. }{ }^{3} \\
{ }^{1,2,3} \text { Abai Kazakh National Pedagogical University, } \\
\text { Almaty, Kazakhstan }
\end{gathered}
$$

\section{HISTORICAL AND SOCIAL FOUNDATIONS OF MODERNISM}

\section{Abstract}

The article discusses theoretical issues and prerequisites of the modernist trend, which influenced the development of literature and art. The main factor influencing the emergence of literary modernism is global change in the historical and social life of human development. Features of European culture and art are considered in the context of literature and art space. The relationship between historical and social factors and factors causing new discoveries in literature and art is revealed. The world of the late 19th century and the beginning of the 20th century was full of new discoveries. Looking at this stage of human development from today's height, we will see that in the twentieth century it underwent multifaceted and radical changes. It began in the European literature of novelty, and also in the Kazakh literature. New and valuable domestic works appeared and the" Golden Fund "of Kazakh literature was replenished with valuable works of Kazakh writers.

Keywords: modernism, literature, art, kazakh prose

$$
\begin{gathered}
\text { Асылбекульь С., }{ }^{1} \text { Аширов Ж.С., }{ }^{2} \text { Кутттыбаев Ш.Д. }{ }^{3} \\
{ }_{1,2,3} \text { Казахский национальный педагогический университет им. Абая, } \\
\text { Алматы, Казахстан }
\end{gathered}
$$

\section{ИСТОРИКО-СОЦИАЛЬНЫЕ АСПЕКТЫ МОДЕРНИЗМА}

\section{Аннотация}

В статье рассматриваются теоретические вопросы и предпосылки модернистского направления, повлиявшего на развитие литературы и искусства. Конец XIX и начало XX веков был периодом бурных событий в мировом пространстве. В результате чего, произошли коренные изменения в экономике, социально-культурной и общественной жизни стран. Основным фактором, влияющим на появление литературного модернизма, являются глобальные изменения в исторической и общественной жизни человеческого развития. Особенности европейской культуры и искусства рассматриваются в контексте литературы и художественного пространства. Выявлены взаимосвязь между историко-социальными факторами и факторами, вызывающими новые открытия в литературе и искусстве. Мир конца XIX века и начало XX века был полон новыми открытиями. Глядя на этот этап человеческого развития с сегодняшней высоты, мы увидим, что XX век претерпел многогранные и радикальные изменения. Начавшаяся с Европейской литературы новизна повлияла и на казахскую литературу. Появились новые и ценные произведения казахских писаталей, пополнившие «золотой фонд» казахской литературы .

Ключевые слова: модернизм, литература, исскуство, казахская проза

Kipicпе. XIX ғасыр соңы мен XX ғасырдың алғашқы ширегіндегі әлем шын мәнінде небір дүрбелеңді жаңалықтарға толы болды. Адамзат дамуының осы кезеңдегі сатысына көз салсақ, XX ғасыр басындағы әлемде жанжақты және түбегейлі өзгерістер жүріп жатты. Әлемнің саяси картасында мемелекеттердің шекаралары мен басқару формалары, құрылымдары қауырт өзгерді: бұрынғы колониялардан тәуелсіз мемлекеттер пайда болды, империалистік саясат ұстанған монархиялы мемлекеттер республикаларға қайта құрылымдалып жатты. Тарих сахнасында дәуірлеген Осман, Ресей, Автрия-Венгрия сынды көпұлтты империялар, Қытайдағы Цин әулетімен байланысты Аспанасты империясы және Жапон империялары сияқты дәстүрлі деп атауға болатын империялар, Африка, Америка, Азияның азат елдерін бодандаудан пайда болған Португал, Испан, Ұлыбритан, Француз сынды империал мемлекеттер ескі мемелекеттің-саяси құрылымның күні құрдымға жақындағанын түсінді. XIX ғасыр соныңдағы қазақ сахарасы бодан ел есебінде Ресей мемлекетінің империалистік ықпалында болып, дәстүрлі басқару жүйесі мен елдік сипатында өзгерістерді басынан кешіріп жатты.

Әдістеме. Алпауыт саналған батыс еуропа елдеріндегі өзгерістердің бір саласы ғылым салаларындағы даму болды. XIX ғасыр соңы мен XX ғасыр басы ғылымдағы жаңалықтар дәуір дамуының қарқынын арттыра түсті. 
Ғылымның сан салалы нәтижесі техникалық прогреске тез әсер етіп, күрделі инженерлік құрылымдарға негізделген өндіріс орындары көбейді. Техникалып прогрестің нәтижесінде пайда болған өндіріс орындары мен оның адамның өмірі жақсартуға бағытталған құралдары сол кезеңдегі батыс өркениеті өкілдерінің индустрализацияға бағыттады. Г.Даймлер, К.Бенц, Р. Дизель сынды есімдермен байланысты көлік өндірісі батыс елдерінің тұрмыстық өмірін жаңа деңгейге көтерді. Ғылым мен техникалық прогрестен қанаттанған өндіріс адамдың жаға сапада болуын қажет етті. «За последние двести лет сельское хозяйство полностью перешло на индустриальные рельсы. Разнообразные машины - например, тракторы - взяли на себя задачи, которые раньше выполнялись исключительно за счет мышечных усилий или же не выполнялись вообще» [1, 414 б.]. Өндіріс орындарының әлеуеті социум өкілдерін уранизациялық процеске жегіп, өндірістің «қала қалыптаструшы» рөлі артты. Қала өміріндегі жаңалықтар мен кәсіпорындағы қиындықтар ғасыр адамының танымына да әсер етті деуге болғандай. Мәселен сол кезеңдердегі көлік өндірісінің конвейерлік сипатынан жұмыстың шығармашылық пен ойды көп қажет етпегенін, автоматтандыруға қадам басқанын көруге болады: «Конечным результатом следования этим основным правилам является сокращение требований, предъявляемых к мыслительной способности рабочего, и сокращение его движений до минимального предела. По возможности, ему приходится выполнять одно и то же дело, одним и тем же движением» [2, 35 б.]. Жаппай индустрализациядан туындаған урбанизациялық процесс дәуір адамын қаланың қауырт тіршілігіне бейімдеді. Ғасырлар айырығандағы осы аталған саяси, экономикалық және ғылым саласындағы өзгерістер батыс адамын табиғаттағы орны мен болашақ тағдыры, инсандық миссиясы туралы ойлануға мәжбүрледі. Қайта өрлеу дәуірінен бастау алған рационализм табиғатқа, құдайға тәуелді адамға қанат бітіріп, бірте бірте бұл танымнан егемен етті. Тринитарлы жүйедегі адам болмысының үстемдігі мен ондағы Тәңірі деп аталатын инстанцияның адам сенімінде аз орын алуы, бұрынғы дәуірлердегі құдайға деген сенімнің ғылыми таныммен алмастырылуы адамды табиғат пен қоршаған ортада жалғыз қалдырды. Ф.Ницше топшылаған «Құдайды өлтіріп алған» адамзат, ғылыми техникалық прогреске ие арта отырып осы позицияға өзін қойды да «Жоғарғы адам» концепциясымен танылды. Тринтарлы жүйедегі бір инстанцияның жойылуы мен адамға тән рационализм мен сенсуализмді алдыңғы орынға шығарды. «Теологиямен күресте ғылым ақырында дербестікке қол жеткізді, діни сенім мен ғылыми таным салаларының межеленуі орын алды. Теология болмыс мәнінің мәңгілік мәселелерін және адам өмірінің мақсаттарын, яғни философия саласындағы тәжірибеге ғана негізделген (эмпириялық) білімдер шектерінен тыс рухани мәселелерді өзіне қалдырды да, ал әлемнің қалай құрылғанын зерттеуді бүтіндей ғылымға берді [3,16]. Алайда, әлемдік жаратылыстағы адами болмыс табиғатын ашуға талпынудың басты осы жүйесі қауырт дамушы социум санасында тез тоқырауға ұшырады: «Біз өз ата-бабаларымыздан әлдеқайда қуатты екенімізді түсіндік, бірақ одан бақытты екенімізді сезіне алмадық» [1,518]. XIX ғасыр соңындағы Батыс қоғамындағы тарихи-әлеуметтік оқиғалар мен болмысты танудың қарқынды жаңа жолының салдарынан батыс адамы XX ғасырдан қорқыныш пен үрей, хаос пен ақырзаман күтті.

Талқылау. Модернизм ұғымының терминдік мәнін мәдениет, әдебеит пен өнер салаларына ғана телімей, кең мағынасында адамзат дамуының тарихи даму тәжірибесі ретінде қарасақ, модерннің бүкіл адамзатқа ортақ, өзара байланысты екіжақты үдеріс екені анықталады. Оның бірі ғылыми-техникалық прогрес, өндіріс саласындағы жетістіктер тудырған қоғамдағы әлеуметтік-экономикалық өзгерістер. Яғни қоғам өміріндегі (урбанизациялық процестер, жұмысшы күшінің жаңа сапа мен сипатқа ауысуы, саяси-әлеуметтік қозғалыстар, формациялық өзгерістер (мысалы капиталим мен социализм) модернизация, яки жаңару болса, екіншісі осы үдерістердің салдарының жеке индивид-тұлғаға, қоғам мүшелеріне әсерінің көрсеткіші мәдениеттегі, әдебиет пен өнердегі модернизм. Модернизмге жаңашылдық тән. Жаңашыл идея, не бастаманың барлығына ортақ белгі өзіне дейінгі классика саналған сара жолдан біршама бас тартып, өз концепциясына сәйкес сан тараулы тыңға түрен түсіреді. Мәдениет контекстегі модерн мен қоғамдық-әлеуметтік даму сипатындағы модернизация бірінен бірі туындайды, бірін бірі толықтырады. Осы тарихи-мәдени жағдайлар тоғысындағы инсан заман ағымына сәйкес транформацияланады. «Тұлғаның осылайша индивидтік қуатының артуы және тәжірибесінің кеңеюі артуы арқылы трансформациялануы субективтіліктен объективтілікке қарай дамудың жалпы концепциясы арқылы кері байланыс түзеді: өзіндік және экономикалық даму. Модерн - экономикалық үдеріс және мәдени көзқарастар тәжірибесі» [4]. Демек, модернизм жеке дара әдеби бағыт, мәдени құбылыс деп қана қарастырылмайды. Модернизм өзіне дейінгі дәуірлер қалыптастырған Антикалық, Орта ғасырлар, Қайта өрлеу кезеңдері сияқты болмысты танудың таным тудырған тәжірибесі. Модернизм мәселесін қозғағанда оның оның пайда болуының алғышарттары, қалыптасу уақыты мен кезеңдерін сөз өтпей кету мүмкін емес. Модернизм туралы зерттеулер оның басым бөлігінің өнер салаларымен байланысты екендігіне баса назар аударады. Шындығында да, модерндік таным нәтижесіндегі жетекші идеялар сол кезеңдегі тарихи әлеуметтік жағдайлар салдарының көрсеткіші ретінде, алдымен өнер салаларынан бой көрсетті. Мысал ретінде 1863 жылғы Франциядағы сурет өнеріндегі академизм талаптарына сәйкес деп танылмай кері қайтарылғандардың «Қайтарылғандар салонын» айтуға болады. Академизм талаптары негізінде іріктелетін көрмеге осы жылы келіп түскен бес мың дана жұмыстың үш мыңы қайтарылған екен [5]. Бұл жайт сол дәуірдің өзінде академиялық қасаңдық бұғауынан босауға талпынған, жаңа әдіс, соны тәсіл іздегендердің молдығын да байқатады. Осы жылғы ресми көрмеден шеттетілгендердің ішінде кейіннен импрессионизмнің бастауында тұрған Клод Моне, Эдуард Мане, Пьер Огюст Ренуар сынды суретшілердің болған. Осы кезеңдердегі әдеби шығармалардың да идеялық және баяндау тәсілдеріндегі жаңашылдықтар лебі есті. Модернистік дүниетанымға тән идеяның көріністері Ф.Достоевский, Ш.Бодлер, А.Рембо, т.б. сынды қаламгерлерден байқалып жатты. Осылайша, XIX ғасыр соңы мен XX ғасыр басындағы саяси және көркемөнер тарихын зерделей отырып, модернизмнің 
қалыптасу арналары мен алғышарттарын, бастауларын анықтауға болады. Әдебиет пен өнер тарихында модерндік көзқарас пен модернистик бағыт XIX ғасыр соңы мен XX ғасыр басында құбылыс ретінде қалыптасты. Тарихифилософиялық контекстегі модернизмді Еуропа философиясына тән идеологиялық ағым ретінде түсінеміз. Осы контекстегі модернизм өз идеологиясы арқылы классикаға айналған құндылықтарды шеттетін, дәстүрлі қоғамға қарсы шықты. Дүниетаным ретіндегі модернизмның басты белгісі жаңашылдықтың дәстүрден басым болғандығында жатыр.

Нәтиже. Модернизмнің тұлғалық және ғылыми танымға сүйенетін дүниетанымдық идеология ретіндегі бастаулары өнер тарихындағы модернизмнен әріде жатқандығы байқалады. Бұл бағыттың философиялық негіздерінің қалыптасу хронологиясы Жаңа Дәуірдің рационалистік философиясының хронологиялық уақытымен тұстас келеді. Философиялық контекстегі модернизм болмысты танудағы адамның, адам санасының жетекші позицияда болуынан туындайды. Біз сөз етіп отырған кезеңдердегі адам мен оның әлеуметтік (урбанизация мен индустриализация) тұрмысы, әлеуметтік орта мен тұлғаның қарым-қатынасында индивидтік сападағы адамға жетекші рөл берілді. Модернизм адамды баршаның бастауында тұрған ұлы күш ретінде тани отырып, өзін едейінгі адам қолымен жасалған жәдігерлер мен құндылықтарды терістеді. Қай кезеңдегі болмасын жаңа дүниетанымға тән қасиет-белгі - өзіне дейінгіні теріске шығару әсіресе модернизмде айқын байқалды және қауырт жүргізілді. Өткенді терістеу модернизм бағыты көрініс берген өнердің барлық салаларында жүргізілді.

Кең мағынасындағы модернизмнің концептуалды мазмұны төмендегідей белгі-ерекшеліктер тұрды:

1. Өзіне дейінгі транцсендентальды ақиқатқа емес, Адамға, адам санасына деген сенім

2. Ғылым мен технологиялық жаңалықтарға сүйену;

3. Өнер мен мәдениетте дәстүрді емес жаңашылдыққа басымдық беру;

4. Өз бастауларына да күмән таныту, яки оларды да терістеу.

Адамзат өміріндегі осы бір орасан жылдардың шындығын, ондағы адам жанының түрлі әлеуметтік орта тудырған келеңсіздіктермен арпалысын молынан суреттеп, дәл айшықтаған өнер - әдебиет болды. Өйткені әдебиеттің айтары - өмір шындығы. «Әдебиет арқылы жеткізілетін шындық, біздің түсінігімізде, әдебиетте көрініс табатын шындық, яғни, жүйелі және концептуалды түрде көркем әдебиеттің шеңберіннен тысқарыда тұрып, қаламгердің көмегімен шығармада суреттелетін философия. Бұл тұрғыдан алғанда Данте шығармаларындағы ақиқат - католиктік теология мен схоластикалық философияның көрінісі $[6,53]$. «нерде де сөздің кең мағынасында өмір көрініс тауып отыр. Көпшілік жағдайларда жазушылар мен ақындар, басқа да өнер қайраткерлері қоғам өмірінің бір қарағанда әлеумет үстінен көрінбейтін терең түбінде жатқан құбылыстарын көргендей болады және көркемдік құралдар арқылы оларды халыққа жеткізіп отырады» [3, 7]. XX ғасыр басындағы әлеуметтік орта өміріндегі өзгерістерді, мәдениет пен өнер салаларындағы классикаға айналған эстетиканың жаңалануын әсіресе, әдебиет сезінді. Сөз өнеріндегі модернизм өмірдің адам сезінген нәзік иірімдерін түрлі тәсілдер арқылы жаңа дүниетанымды жеткізді.

Қорытынды. Әдебиеттегі модернизм - ілкі бастауларын өз заманындағы адамның әлеуметтік өміріндегі өзгерістердін, рухани дағдарыстардан алатын, тарихи көркемдік тәжірибені теріске шығарып, соны форма жаңа мазмұн негізінде дүниені көркем пайымдауды мақсат тұтатын әдеби бағыт. Әдеби модернизмнің қалыптасу себептері мен тарихи-әлеуметтік алғышарттары өзге өнер түрлерімен сабақтас. Әдебиеттегі модернизм XIX ғасырдың соңғы онжылдығында туып, Бірінші дүниежүзілік соғыс тудырған салдардың әсерімен XX ғасырдың жиырмасыншы жылдарында Еуропа мен АҚШ әдебиетінде шырқау шыңынан көрінді. Дүниетаным жаңашылдығы модернизмге ұлтаралық сипат дарытты да, өзіне дейінгі әдеби-мәдени дәстүрге дамытуды емес, теріске шығаруды мақсат еткен төңкерісшіл рухта қалыптасты. Еуропа мәдениетіндегі әдеби мәдени дәстүр жалғастығының болмауын, тоқырауын екі себеппен түсіндіруге болатындай. Бірі классикалық шығармадағы идеялық бөліктің замана үрдісіне сай келмеуі болса, екіншісі жазудың техникалық (баяндау стиілі, автор мен қаһарман қарым қатынасы) тұрғыдан түгесілуі деп таныды. Бұл жайттарға өзгерімпаз замандағы оқырманның талғамы да әсер етті. Осы себепті де әдеби модернизм үшін реализмдегі автордың кейіпкерден басымдығы емес, әлемді көркемдік тұрғада таныудағы даралық шығармашылық сипаты маңызды саналды. Дәстүрлі гуманистік мәдениеттің құлдырауында өмірге келген модернизм жалпыадамзаттық гуманистік идеялар жолындағы текетіресті емес, адамның ішкі әлеміндегі дағдарысты сөз етті. Модернистік шығармалардағы кейіпкердің ішкі әлемінің алдыңғы лектен көрінуі адамды қорғаған сыртқы әлемнің дегуманизациясынан (Х.Ортега и Гассет термині) туындап жатты. Модернистер үшін сыртқы әлем суық та қатал кейіпте көрінеді. Әдеби модернистік пайымдауда адамның өмірі қысқа да бір сәттік, «қамшының сабындай» ғана кезең. Өмір сүруші субъект әлемнің баянсыздығы мен ондағы осы ыңғайдағы трагизмді бағдарлай алмауы мүмкін. Ал жазушының қаламгерлік миссиясы - осы баянсыздық ішіндегі қорқыныш пен ұлылықты, әсемдікті көрсету. Адамзат тарихында адам өмірінің мәнділігі оның қауымдасу қасиетімен, социуымдық ортасымен маңызды екені белгілі. Әдебиеттегі әлеуметтік проблематика әр кезде де көркемдік назардан тыс қалмайтын-ды. Бұл әсіресе реализм тұсында өткір мәселе ретінде өзектеліп, оның социлистік ыңғайы «адам адамға дос, бауыр» тезисімен түзілетін. Бұл тұрғыда әдеби модернизм кейіпкерін жалғыз қалдырады: әлеуметтік проблематика мен орта тұлғаның болмысын ашу, индивидттік портретін толықтыру мақсатында ған жанама түрде жасалады. Бұл ыңғайда М.Әуезов, Ж. Аймауытов, М.Жұмабаев, С. Сейфуллин, С.Ерубаевтан бастап бүгінге дейін шеру тартатын туындыларымыздан болмыстың осы сипатын әр түрлі дәрежеде байқай аламыз.

Модеризмнің дәуір сыны айқындаған айқын белгілерін төмендегідей түйіндеуге болады:

- адамның (кейіпкердің) ішкі әлеміне үңілуге ерекше құлшыныс таныту; 
- адам мен өнерді дара құндылықтар ретінде бағалау;

- шығармашылық интуицияға басымдық беру;

- әдебиетті адам жаны мен болмысының ең құпия, нәзік түкпірлеріне енуге және әлемді рухтандыруға қабілетті құбылыс деп тану;

- жазу техникасындағы (құралдарындағы) жаңашылдық (метатіл, символ, мифошығармашылық, сана ағымы);

- әлемді әсемдік пен өнер заңдылықтарына бағндыра отырып өзгерту (дадаистер мен сюррелистердің өнердегі радикалды ізденістері).

Көркемдік кеңістікте модернистерді қызықтыратын проблематика әлеуметтік мәселе емес, тұлға ретіндегі адам, адамның саналы және бейсаналы бастауларындағы күрестен туындайтын өміртанымдық құбылыстары. Модернистік шығарма кейіпкері өз сезімі мен қабылдауларымен тұтастықта қарастырылады, өз субъективті болмысының эпиценрі ретінде бағалануымен құнды. Модернистік дүниетаным негізінде өрістеген көркемдік кеңістіктегі адамды әдеби қаһарман деп бағалау қиын. Қаһармандық - әлеуметтік құбылыс, әдеби қаһарман - шығарма мазмұнын ашатын сюжеттік әрекетті айқындаушы. Ол романтизм мен реализм бағыттарындағы шығармаларға тән болып келетін. Ал модернистік шығарманың «қаһарманы» - әлеуметтік беделдің төменгі шектік сызығындағы адам, әркім және кез келген. Көркемдік әлем тарихындағы қаһармандар Антикалық дәуірде - құдайлар, ондан кейінгі әдебиет дамуында патшалар мен аристократтар болып, модернизм дәуірінде әркім және кез келген әлеуметтік статустағы адам болып түйінделді. Модернист жазушылардың қаламынан өзіне дейінгі әдебиет баса назар аудара қоймаған адам жанының ішкі дүнесі мен бейсаналы әлемінен өрілген болмыс суреттері туындады. Өзіне дейінгі моралдық этика әспеттеуге мүмкіндік бермеген проблемалар әдебиет әлемінен көрінді. Бейсаналықпен байланысты түсіндірілетін нәпсі мен қоғамға қатысты бейсаяси қатынас - төңкерістік рухтың белгісі ретінде танылды. Бейсаясилық (аполитичность) белгінің бір сипаты - «өнер - өнер үшін» (pp. l'art pour l'art) қағидатымен қабысып жатса, әдебиетттен туындайтын адамгершілік игіліктерді кейінгі орынға ысырды. Қайта керісінше қоғам өмірінен жекеге бағдар тартқан кейіпкер өмірін рационалды үдерістерді жоққа шығара отырып (мәселен, әлеуметтік статус тұрғысындағы кішкентай кейіпкер, коммивояжер Грегор Замзаның иррационалды құбылысы) эстетикалық үйлесім тудыруға тырысады. Өйткені модернистік әдебиеттегі басты нысан - қоғамдық шиеленіс емес, сол қоғам мен адам арасындағы қайшылықтың адамның дағдарысты санасындағы көрінісі.

\section{Пайдаланылган ддебиеттер тізімі:}

1 Харари Ю.Н. Sapiens. Краткая история человечества [пер. с англ. Л. Сумм]. - М.: Синдбад, 2016. - 520 с.

2 Форд Г. Моя жизнь. Мои достижения. М. Астрель 2012

3 Артемьев А., Мырзаль С. Ғыльим тарихы және философиясы: оқу құральл. - Алматы: «Бастау» баспасы, 2011. - 432 бет.

4 Кук Ф. Модерн, посмодерн и город // Логос 3 (34) 2002 г //https://ruthenia.ru/logos/number/34/15.pdf

5 Салон отверженных // https://ru.wikipedia.org/wiki/салон отверженных

6 Бөпежанова Ә., Қодар Ә. «Өнер - өмір, өнер- көркем текст немесе таным тайталастары» // Қазақ ддебиеті № 28 (2658) 14.07.2000ж.

7 Rene Wellek and Austin Warren. Theory of Literature (Перевод с английкого А. Зверева, В.Харитонова, И.Илин). М.: «Прогресс», 1978. - 325cmp.

\section{Reference:}

1. Harari Iu.N. Sapiens. Kratkaia istoria chelovechestva [per. s angl. L. Summ]. - M .: Sindbad, 2016. - 520 s.

2. $\quad$ Ford G. Moia jizn. Moi dostijenia. M. Astrel 2012

3. Artemev A., Myrzaly S. Ğylym tarihy jäne filosofiasy: oqu qūraly. - Almaty: «Bastau» baspasy, 2011. - 432 bet.

4. Kuk F. Modern, posmodern i gorod //Logos 3 (34) 2002 g//https://ruthenia.ru/logos/number/34/15.pdf

5. Salon otverjennyh // https://ru.wikipedia.org/wiki/salon_otverjennyh

6. Böpejanova Ä., Qodar $\ddot{A}$. «Öner - ömır, öner- körkem teks nemese tanym taitalastary» // Qazaq ädebietı № 28 (2658) 14.07.2000j.

7. Rene Wellek and Austin Warren. Theory of Literature (Perevod s angliskogo A. Zvereva, V.Haritonova, I.Illin). M.: «Progres», 1978. - 325str. 